\title{
Pyrolyzed agricultural wastes for improving degraded soil, nutrient use efficiency and growth performance of maize
}

\author{
Onwudike Stanley Uchenna and Onwubiko Jadidiah Solomon \\ Soil Science and Technology Department, Federal University of Technology Owerri, Nigeria \\ [Received: September 20, 2019 Accepted: January 01, 2020 Published Online: January 15, 2020]
}

\begin{abstract}
The need for cheap and affordable alternate sources of plant nutrient inputs to boost the nutrient level of degraded arable farmlands has been a major concern for soil scientists. In 2018, a field study was carried out under rain-fed conditions to evaluate the effect of palm waste biochar (PWB), poultry litter biochar (PLB) and inorganic fertilizer on the properties of soil, $N$ and $P$ use efficiency on a sandy Ultisol. The treatments consisted of $T_{1}$ (control), $T_{2}$ (625 $\mathrm{kg} \mathrm{ha} a^{-1} \mathrm{NPK}$ fertilizer), $T_{3}\left(10 \mathrm{th} a^{-1} P W B+625 \mathrm{~kg} \mathrm{ha}^{-1} \mathrm{NPK}\right.$ fertilizer), $T_{4}\left(10 \mathrm{th} \mathrm{a}^{-1} \mathrm{PLB}+625 \mathrm{~kg} \mathrm{ha} \mathrm{a}^{-1} \mathrm{NPK}\right.$ fertilizer), $T_{5}\left(5 \mathrm{tha}^{-1} \mathrm{PWB}+5 \mathrm{th} \mathrm{a}^{-1} \mathrm{PLB}+625 \mathrm{~kg} \mathrm{ha}^{-1} \mathrm{NPK}\right.$ fertilizer $)$ and $T_{6}\left(10 \mathrm{t} \mathrm{ha} \mathrm{a}^{-1} \mathrm{PWB}+10 \mathrm{tha} \mathrm{I}^{-1} \mathrm{PLB}+625 \mathrm{~kg} \mathrm{ha^{-1 }} \mathrm{NPK}\right.$ fertilizer). These treatments were arranged in a randomized complete block design and replicated three times. Data were analysed using Analysis of Variance (ANOVA) and significant effects among treatment means were determined using Fishers Least Significant Difference (F-LSD) at a 5\% probability level. Results showed that biochar application significantly $(\mathrm{p}=0.05)$ reduced soil bulk density by $9.9 \%$, increased soil organic matter by $28.4 \%$, total exchangeable bases by $34.8 \%$ and raised soil pH by 19.2\%. The number of leaves, plant height and leaf area of maize were significantly higher in the amended plots than that of the control plots after six weeks of planting. Plots amended with

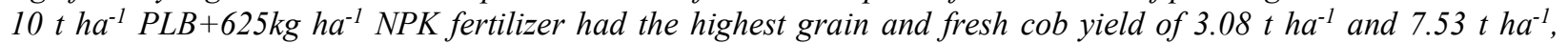
respectively, while the least values were obtained in the control plots $\left(2.18 \mathrm{t} \mathrm{ha} \mathrm{a}^{-1}\right.$ and $4.03 \mathrm{th} \mathrm{h}^{-1}$, respectively). The highest values of nitrogen uptake (70.84 $\left.\mathrm{kg} \mathrm{ha}^{-1}\right)$, physiological efficiency of $\left(27.47 \mathrm{~kg} \mathrm{ha} \mathrm{I}^{-1}\right)$, phosphorus uptake (78.54

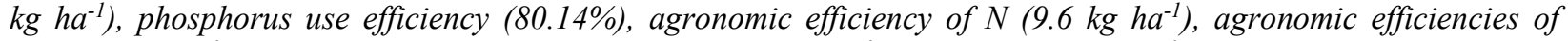
$P\left(22.02 \mathrm{~kg} \mathrm{ha}^{-1}\right)$, partial factor productivity of $N\left(32.85 \mathrm{~kg} \mathrm{ha}^{-1}\right)$ and $P\left(75.34 \mathrm{~kg} \mathrm{ha}^{-1}\right)$ as well as $N$ physiological efficiency (30.6 $\mathrm{kg} \mathrm{ha}^{-1}$ ) were obtained in plots amended with $10 \mathrm{t} / \mathrm{ha} P L B+625 \mathrm{~kg} \mathrm{ha}^{-1} \mathrm{NPK}$ fertilizer. Therefore, application of $10 \mathrm{th} \mathrm{h}^{-1}$ PLB $+625 \mathrm{~kg} \mathrm{ha}^{-1}$ NPK fertilizer is recommended for improved $N$ and P use efficiencies, $N$ and $P$ uptakes, yield performance of maize and improvement in the soil properties of a degraded acidic soil.
\end{abstract}

Keywords: Biochar, partial factor productivity, pyrolysis, soil amendment, soil fertility, ultisol

\section{Introduction}

In South-eastern Nigeria, there has been a reduction in the food supply over the years due to low soil nutrient levels and high level of soil degradation (Onwudike et al., 2015). Researchers have recommended application of mineral fertilizer to boost food production (Amanullah, et al., 2014; Seran et al., 2010; Stewart et al., 2005). However, due to the negative effects of inorganic fertilizers such as nutrient imbalance, nutrient antagonism, soil acidification (Onwudike, et al., 2015), poor residual effect, use of organic fertilizers has been advocated (Nwonuala, et al., 2013; Onwudike et al., 2015). Sole application of chemical fertilizer generates several deleterious effects on the environment and human health (Aisha et al., 2007). Nutrient elements in chemical fertilizer are easily lost through leaching and evaporation and could cause dangerous environmental pollution such as water pollution in fields along watersheds (Stewart et al., 2005). Therefore, there is need to search for materials that can counteract the negative effect of mineral fertilizers by improving the nutrient use efficiency (NUE) of crops, while considering the triple bottom line of sustainable agriculture which includes social responsibility, economic prosperity and environmental stewardship especially in South-eastern Nigeria where the soils have been designated as highly weathered, leached and acidic (Onwudike et al., 2015).

Application of pyrolyzed agro-wastes (biochar) made from palm waste and poultry droppings have the potential to reduce the need for mineral fertilizers, as well as improve soil physico-chemical properties (Muhammad et al., 2018). These materials are cheap, available and less bulky than mineral fertilizers and organic manures. Pyrolyzed agro-

*Email: stanley.onwudike@futo.edu.ng 
wastes popularly known as biochar is fine-grained charcoal produced through pyrolysis or heating highly carbonated organic material in the absence or low supply of oxygen. It does not decompose easily and its effect last for hundreds of years. Biochar application on soils has significant effect on physical and chemical properties of soil (Major et al., 2010, Muhammad et al., 2018). Onwudike et al. (2015) observed that burnt carbonaceous agricultural wastes increased plant height, economic yield and leaf area of maize in relation to the un-burnt agricultural wastes.

Nutrient Use Efficiency (NUE) is a measure of the ability plant utilize available nutrients in the soil and it is the yield (biomass) per unit fertilizer input (Malcom, 2012). Nitrogen or phosphorus use efficiency estimates the quantity of total biomass that is being produced per unit of nitrogen or phosphorus absorbed by plants. Nutrient Use Efficiency is an important concept in the crop production evaluation system. According to Paul et al. (2014), the intention of nutrient use efficiency is to boost the overall performance of cropping systems by providing economically optimum nourishment to crop and to minimizing nutrient losses from the field. Pyrolyzed materials contain essential nutrients with high $\mathrm{pH}$ level that reduces the acidity of acidic soils thereby improving nutrient use efficiency. Limited literature is available regarding the effects of pyrolyzed agro-wastes on nutrient use efficiency in degraded acidic Ultisol.

\section{Materials and Methods}

The study was performed during the planting season of 2018 at the University Research Farm, Federal University of Technology Owerri, South-eastern Nigeria. The area lies between the latitude $5^{\circ} 22^{\mathrm{I}} 43^{\mathrm{II}} \mathrm{N}$ and longitude $6^{\circ} 59^{\mathrm{I}} 37^{\mathrm{II}} \mathrm{E}$. The area has mean annual rainfall and temperature of $2000-2500$ $\mathrm{mm}$ and $25-30^{\circ} \mathrm{C}$, respectively. The study area is a humid tropical region with soil type classified as typic-haplustult (FDALR., 1985).

The study area was $180 \mathrm{~m}^{2}$. This area was mapped out, and manual clearing was done using cutlass and spade, making sure all stumps were removed. Six experimental plots were mapped out and each plot measured $2 \mathrm{~m} \times 2 \mathrm{~m}$. Each experimental plot was replicated three times given a total of eighteen experimental plots. There was $1 \mathrm{~m}$ space between one plot and another and $1 \mathrm{~m}$ gap between the blocks. The experiment was arranged using randomized complete block design (RCBD). The experimental plots were tilled and properly labelled on the basis of the treatment. To minimize the pest attack and to prevent human intrusion, a fence of Bamboo sticks and ropes was built around the experimental plots.
Maize (Zea mays L.) cultivar (Wacot) was bought from Imo State Agricultural Development Programme. One bag of poultry litter (manure) and four bags of oil palm bunch waste were obtained from Imo State Agricultural Development Programme. The materials were pyrolyzed at $300{ }^{\circ} \mathrm{C}$ using a well-constructed biochar drum under controlled condition. Treatments comprised of: T1 as Control, T2 $=0 \mathrm{t} \mathrm{ha}^{-1}+625$ $\mathrm{kg} \mathrm{ha}^{-1} \mathrm{NPK}, \mathrm{T3}=10 \mathrm{t} \mathrm{ha}^{-1} \mathrm{PWB}+625 \mathrm{~kg} \mathrm{ha}^{-1} \mathrm{NPK}, \mathrm{T} 4=$ $10 \mathrm{tha}^{-1} \mathrm{PLB}+625 \mathrm{~kg} \mathrm{ha}^{-1} \mathrm{NPK}, \mathrm{T} 5=5 \mathrm{tha}^{-1} \mathrm{PWB}+5 \mathrm{tha}$ ${ }^{1}$ PLB $+625 \mathrm{~kg} \mathrm{ha}^{-1}$ NPK, T6 $=10 \mathrm{tha}^{-1} \mathrm{PWB}+10 \mathrm{tha}^{-1}$ PLB $+625 \mathrm{~kg} \mathrm{ha}^{-1}$ NPK.

Treatments were applied using broadcasting method on the tilled plots after weighing $4 \mathrm{~kg}\left(4 \mathrm{~m}^{2}\right)^{-1}$ of the PWB and PLB, $4 \mathrm{~kg}\left(4 \mathrm{~m}^{2}\right)^{-1}$ of PWB + PLB, and $2 \mathrm{~kg}\left(4 \mathrm{~m}^{2}\right)^{-1}$ of PWB + PLB biochar. These quantities gave $10 \mathrm{tha}^{-1} \mathrm{PWB}$ and PLB, $10 \mathrm{tha}^{-1}$ of PWB+PLB and $5 \mathrm{tha}^{-1} \mathrm{PWB}+5 \mathrm{tha}^{-1}$ PLB per experimental plot, and $0.25 \mathrm{~kg}\left(4 \mathrm{~m}^{2}\right)^{-1}$ of NPK 15:15:15 fertilizer. Planting of test crop was done 7 days after treatment application to allow incubation process. Three maize seeds were planted per hole at a planting space of 75 $\mathrm{cm} \times 25 \mathrm{~cm}$ between and within rows at a depth of $4 \mathrm{~cm}$ on the 10th of April 2018. Germination started 5 - 6 days after planting (DAP) and the supply of empty stands was done immediately. One week of planting, germinated seeds were thinned down to one plant per stand making 53,333 plants/ha and 21 plants per plot. $625 \mathrm{~kg} \mathrm{ha}^{-1}$ of NPK fertilizer was applied manually using ring application method at $8-10 \mathrm{~cm}$ radius to all plots excluding control plot. Weeds were controlled manually using hoe and by hand picking to keep the plots weed-free and this was done regularly as the need arose while 10\% Saproca-neem (Azadiracta indica) solution was sprayed on the leaves twice per week during the period of the research for pest control. The crop was harvested on the 6th of July 2018 (12WAP).

Soil samples were collected from each plot at 0-30 cm soil depth using a soil auger attached with a core sampler before and after harvest for soil analysis. The samples were air-dried at room temperature; sieved using $2 \mathrm{~mm}$ mesh size for laboratory analysis. Particle size distribution (PSD) was determined by the Bouyoucos Hydrometer method (Gee and Or, 2002) using sodium hexametaphosphate (calgon) as a dispersant. Bulk density was calculated using the formula by Post and Kwon (2000).

Bulk Density $(\rho \mathrm{B})=\frac{100}{\left(\frac{O . M}{0.244}\right)+\left(\frac{100-O . M}{1.64}\right)} \ldots \ldots \ldots \ldots \ldots . . .1$

Where, O.M $=\%$ Organic matter.

Total porosity was computed as followed $\mathrm{TP}=1-\frac{\rho \mathrm{B}}{\rho \mathrm{d}} \times 100 \quad$ ……...................... 2 
Where, particle density $(\rho \mathrm{d})=2.65 \mathrm{gcm}^{-3}$

Soil $\mathrm{pH}$ was determined in the distilled water at 1:2.5 soil suspension ratio using a $\mathrm{pH}$ meter (Hendershot et al., 1993). Total organic carbon was determined by Walkley-Black wet oxidation method (Nelson and Sommers, 1982). Organic matter was calculated by multiplying total organic carbon (TOC) by a factor of 1.724 (Nelson and Sommers, 1982). Total nitrogen was determined using the modified Kjeldahl method (Bremner and Muvaney, 1982). Available phosphorus was determined according to Olsen and Sommers (1982) method. The exchangeable cations $\left(\mathrm{Ca}^{++}, \mathrm{Mg}^{++}, \mathrm{K}^{+}\right.$, $\mathrm{Na}^{+}$) were extracted with $1 \mathrm{~N}$ neutral ammonium acetate at $\mathrm{pH}$ 7.0 (McLean, 1982). Exchangeable calcium and magnesium were determined with EDTA complexio-metric titration while exchangeable potassium and sodium were read using flame photometer. Exchangeable acidity $\left(\mathrm{H}^{+}\right.$and $\left.\mathrm{Al}^{3+}\right)$ was determined by extraction using $1 \mathrm{~N} \mathrm{KCl}$ (Thomas, 1982) and read titrating with $0.5 \mathrm{~N} \mathrm{NaOH}$ with phenolphthalein indicator. Summation of exchangeable $\mathrm{Mg}, \mathrm{K}, \mathrm{Ca}, \mathrm{Na}$ and exchangeable Hydrogen and Aluminum is used to calculate ECEC (effective cation exchange capacity). Percentage Base Saturation (\% BS) was calculated by dividing total exchangeable cations with ECEC and the quotient multiplied by 100 . The carbon and nitrogen ratio were calculated as used by Brady and Weil (1999). The value of the silt fractions was divided by clay fractions gave silt/ clay ratio. Clay activity was computed by dividing ECEC with percentage clay particles (Brady and Weil (1999).

Four plants were selected randomly and tagged in each plot and used for all the agronomic measurements such as plant height, number of leaves and leaf area. Fresh cob yield was determined using a weighing balance. The number of leaves was determined by counting the number of leaves on the four tagged plants and dividing the total by 4 . Leaf areas of the four tagged plants were measured using meter rule. Length and breadth of the leaves were measured, and values were multiplied by 0.6654 according to Nwafor et al. (2010). Measurement of plant height was done with meter rule (Nwafor et al., 2010). Grain yield was determined using a weighing balance after drying the grains up to $13 \%$ moisture content to get dry mass weight. Straw dry matter was determined using a weighing balance after oven drying to a constant weight. Harvest Index (HI) was calculated according to Agnieszka et al. (2013) as

$\mathrm{HI}=\frac{\mathrm{Grain} \text { yield }(\mathrm{kg} / \mathrm{ha})}{\text { Total biomass produced by the plants }(\mathrm{kg} / \mathrm{ha})} \quad \ldots \ldots \ldots . . .3$

Nutrient uptake $\left(\mathrm{kg} \mathrm{ha}^{-1}\right)$ was determined by using the formula according to (Sharma et al., 2012)
Nutrient uptake $\left(\mathrm{kg} \mathrm{ha}^{-1}\right)=\frac{\text { plant dry weight }(\mathrm{kg} / \mathrm{ha})}{\text { nutrient concentration }(\%)} \times 100 \ldots 4$

Nutrient use efficiency was calculated according to Paul et al. (2014) as

NUE $=$ Percent Fertilizer Recovery $=\frac{\mathrm{NF}-\mathrm{NC}}{\mathrm{R}} \quad \ldots \ldots \ldots . .5$

Where, $\mathrm{NF}=$ total crop nutrient uptake from fertilized plots (grain) $\left(\mathrm{kg} \mathrm{ha}^{-1}\right), \mathrm{NC}=$ total crop nutrient uptake from unfertilized plots (Grain) $\left(\mathrm{kg} \mathrm{ha}^{-1}\right), \mathrm{R}=$ amount of fertilizer (nutrient) applied $\left(\mathrm{kg} \mathrm{ha}^{-1}\right)$.

NUE $(\%)=$ NUE $x 100$............................

Partial Factor Productivity (PFP) was computed using the relationship:

$\mathrm{PFP}=Y / F$ 7

Where, $\mathrm{Y}=$ crop yield with applied nutrients $\left(\mathrm{kg} \mathrm{ha}^{-1}\right), \mathrm{F}=$ amount of fertilizer (nutrient) applied $\left(\mathrm{kg} \mathrm{ha}^{-1}\right)$. Agronomic efficiency (AE) was calculated by

$\mathrm{AE}=(Y-\mathrm{Yo}) / F$ 8

Where, Yo $=$ crop yield without applied treatments $\left(\mathrm{kg} \mathrm{ha}^{-1}\right)$.

Physiological efficiency (PE) was calculated by

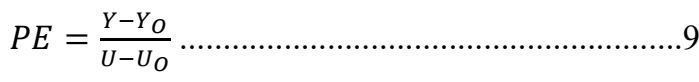

Where, $\mathrm{U}=$ Nutrient uptake in plants receiving fertilizer $(\mathrm{kg}$ $\left.h^{-1}\right)$, Uo $=$ Nutrient uptake in plants receiving no fertilizer $\left(\mathrm{kg} \mathrm{ha}^{-1}\right)$.

Before applying the biochar in the soil, some samples were ground and sieved to less than $0.5 \mathrm{~mm}$ in diameter for the determination of nutrient composition. Total nitrogen was determined using the modified Kjeldahl method while calcium, magnesium, sodium, potassium was determined by subjecting the sample to wet digestion using $25-5-5 \mathrm{~mL}$ of $\mathrm{HNO}_{3}-\mathrm{H}_{2} \mathrm{SO}_{4}-\mathrm{HClO}_{4}$ and the nutrients determined by using the filtrate.

After harvesting, the maize plants (grain + straw) were collected according to the plots. The grains were sundried to about $13 \%$ moisture content and the yield per plot and per hectare was also calculated. The samples were washed with distilled water and oven-dried at $65^{\circ} \mathrm{C}$ for 72 hours. The samples were ground with pestle and mortar to pass a $0.25 \mathrm{~mm}$ pore size sieve and ashed using porcelain crucible. Five $\mathrm{mL}$ of $0.5 \mathrm{M} \mathrm{HCl}$ was added in the ash. 100 $\mathrm{mL}$ of the filtrate was used to determine the nutrient concentration and uptake in maize (Brady and Weil (1999). methods. Significant differences between the 
means were ranked with Fisher's Least Significant Difference (F-LSD) at 5\% probability the level using analysis of variance.

\section{Physico-chemical properties of soil before planting}

The selected pre-planting soil properties are presented in Table 1. The soil was texturally loamy sand with 849.6 $\mathrm{g} / \mathrm{kg}$ sand, $75 \mathrm{~g} \mathrm{~kg}^{-1}$ silt and $75.4 \mathrm{~g} \mathrm{~kg}^{-1}$ clay. These results were similar with the observations of Onwudike et al. (2015) who had related report for soils in Owerri, Imo State, South-eastern Nigeria. The textural class may negatively affect plant growth by exhibiting low water and nutrient retention capacities. The soil was low in available phosphorus, low in $\mathrm{pH}$ (strongly acidic), total $\mathrm{N}$, and exchangeable bases. The bulk density was $1.54 \mathrm{~g} \mathrm{~cm}^{-3}$, which was less than the critical limit for root restriction $\left(1.75-1.85 \mathrm{~g} \mathrm{~cm}^{-3}\right)$ as described by Soil Survey Staff (2003). The organic matter content of the soil was low. The organic matter content was deficient when compared to the critical level of 20-30 $\mathrm{g} \mathrm{kg}^{-1}$ reported by Enwezor et al. (1989). Therefore, since the critical levels of this soil was lower than the critical limits recommended by FAO (2006), the fertility level of these soil needs good nutrient management practices such as biochar application.

Table 1: Soil properties before planting (0-30 cm depth)

\begin{tabular}{ll}
\hline Properties & Value \\
\hline Sand $(\%)$ & 84.96 \\
Silt $(\%)$ & 7.50 \\
Clay $(\%)$ & 7.54 \\
Textural class & Loamy sand \\
Total Porosity $(\%)$ & 41.77 \\
Bulk Density $\left(\mathrm{g} \mathrm{cm}^{-3}\right)$ & 1.54 \\
Clay activity & 0.05 \\
Silt/Clay ratio & 0.24 \\
Total Nitrogen $\left(\mathrm{g} \mathrm{kg}^{-1}\right)$ & 0.56 \\
Organic Carbon $\left(\mathrm{g} \mathrm{kg}^{-1}\right)$ & 6.36 \\
$\mathrm{C} / \mathrm{N} \mathrm{ratio}$ & 11.36 \\
Organic Matter $\left(\mathrm{g} \mathrm{kg}^{-1}\right)$ & 10.96 \\
Available Phosphorus $\left(\mathrm{mg} \mathrm{kg}^{-1}\right)$ & 5.21 \\
Exchangeable Acidity $\left(\mathrm{H}^{+}+\mathrm{Al}^{3+}\right) \mathrm{Cmol} \mathrm{kg}^{-1}$ & 0.91 \\
Exchangeable calcium $\left(\mathrm{Cmol} \mathrm{kg}^{-1}\right)$ & 1.4 \\
Exchangeable Magnesium $\left(\mathrm{Cmol} \mathrm{kg}^{-1}\right)$ & 1.01 \\
Exchangeable Sodium $\left(\mathrm{Cmol} \mathrm{kg}^{-1}\right)$ & 0.04 \\
Exchangeable Potassium $\left(\mathrm{Cmol} \mathrm{kg}^{-1}\right)$ & 0.12 \\
ECEC $\left.(\mathrm{Cmol} \mathrm{kg})^{-1}\right)$ & 3.48 \\
Base Saturation $(\%)$ & 73.85 \\
\hline
\end{tabular}

\section{Chemical properties of the pyrolyzed Agro- wastes}

Proximate analysis of pyrolyzed agro-wastes is presented in Table 2. High $\mathrm{pH}$ in biochar materials indicated that they could be effective as alkaline materials which when added to the soil can increase the soil $\mathrm{pH}$ of the study site. Thus, the biochars (PLB and PWB) with their high $\mathrm{pH}$ values could be effective as liming materials. Soil organic carbon $\left(97.53 \mathrm{~g} \mathrm{~kg}^{-1}\right)$ and total nitrogen $\left(22.30 \mathrm{~g} \mathrm{~kg}^{-1}\right)$ of PLB were higher than that of PWB (46.55 $\mathrm{g} \mathrm{kg}^{-1}$ and $15.17 \mathrm{~g} \mathrm{~kg}^{-1}$ ), respectively. There was higher $\mathrm{P}$ content in the pyrolyzed PWB (0.51 $\left.\mathrm{g} \mathrm{kg}^{-1}\right)$ and PLB $\left(0.41 \mathrm{~g} \mathrm{~kg}^{-1}\right)$ and therefore, they could serve as good soil amendments.

\section{Results and Discussion}

\section{Soils properties:}

The effects of the pyrolyzed agro-wastes on physical parameters of soil are presented in Table 3. No significant change was observed in soil texture. It supports previous work performed by Fitzpatrick (1986) who suggested that soil texture is a function of an inherent characteristic of soil which can be influenced by parent material and climatic conditions over time. The pyrolyzed agro-wastes indicated significant $(p<0.05)$ effect on soil bulk density. Control plots and plots treated with $625 \mathrm{~kg} \mathrm{ha}^{-1}$ NPK (T2) recorded bulk densities of $1.51 \mathrm{~g} \mathrm{~cm}^{-3}$ and $1.49 \mathrm{~g} \mathrm{~cm}^{-3}$, respectively, which are higher than the bulk densities of plots amended with biochar. Plots amended with $10 \mathrm{t} \mathrm{ha}^{-1} \mathrm{PWB}+625 \mathrm{~kg} \mathrm{ha}^{-1} \mathrm{NPK}$ (T3) and $10 \mathrm{t} \mathrm{ha}^{-1}$ PLB $+625 \mathrm{~kg} \mathrm{ha}^{-1}$ NPK (T4) recorded bulk densities of 1.38 and $1.36 \mathrm{~g} \mathrm{~cm}^{-3}$, respectively, and these values were lower than the bulk density of soils which were not amended with biochar. This was in line with the reports of Ekebafe et al. (2013), Lehmann et al. (2011) and Major et al. (2010) who found a significant decrease in bulk density in biochar-amended soils. The values of total porosity were significantly $(p<0.05)$ different between plots amended with biochar and plots not amended with biochar (Tale 3). Results showed a similar trend with bulk density confirming the inverse correlation between the density of the soil and total porosity. The trend in the decrease in soil bulk density was $\mathrm{T} 4>\mathrm{T} 3>\mathrm{T} 6=\mathrm{T} 5>\mathrm{T} 2>$ control. This was in concord with the observations of Ekebafe et al. (2013) and Major et al. (2010) who observed an increase in soil macro and mesopore volume, increased organic matter content and water transmission rate in soil amended with biochars.

Table 4 showed the effect of the pyrolyzed agro-wastes on soil chemical parameters. Amended plots significantly ( $p$ $<0.05$ ) raised soil $\mathrm{pH}$ in relation to plots free from biochar. 
Table 2: Nutrient composition of biochar material

\begin{tabular}{lll}
\hline Chemical Properties & PWB & PLB \\
\hline Organic carbon $\left(\mathrm{g} \mathrm{kg}^{-1}\right)$ & 46.55 & 97.53 \\
Total nitrogen $\left(\mathrm{g} \mathrm{kg}^{-1}\right)$ & 15.17 & 22.3 \\
$\mathrm{C} / \mathrm{N}$ ratio & 3.07 & 4.37 \\
Available phosphorus $\left(\mathrm{g} \mathrm{kg}^{-1}\right)$ & 0.51 & 0.41 \\
$\mathrm{pH}\left(\mathrm{H}_{2} \mathrm{O}\right)$ & 10.48 & 9.67 \\
Exchangeable calcium (\%) & 3.763 & 7.7 \\
Exchangeable magnesium (\%) & 0.367 & 1.859 \\
Exchangeable sodium $(\%)$ & 0.207 & 0.316 \\
Exchangeable potassium $(\%)$ & 0.157 & 0.183 \\
\hline
\end{tabular}

PWB $=$ palm waste biochar, PLB = poultry litter biochar

Table 3: Effect of pyrolyzed agro-wastes on soil physical properties

\begin{tabular}{|c|c|c|c|c|c|c|c|}
\hline Treatment & Sand (g kg-1 & Silt $\left(\mathrm{g} \mathrm{kg}^{-1}\right)$ & Clay $\left(\mathrm{g} \mathrm{kg}^{-1}\right)$ & TC & BD $\left(\mathrm{gcm}^{-3}\right)$ & TP (\%) & SCR \\
\hline $\mathrm{T}_{1}$ & 840.2 & 77.8 & 82.0 & LS & 1.51 & 43.20 & 0.95 \\
\hline $\mathrm{T}_{2}$ & 838.7 & 74.2 & 87.1 & LS & 1.49 & 43.77 & 0.85 \\
\hline $\mathrm{T}_{3}$ & 830.6 & 75.4 & 94.0 & LS & 1.38 & 47.92 & 0.80 \\
\hline $\mathrm{T}_{4}$ & 826.7 & 74.0 & 99.3 & LS & 1.36 & 48.68 & 0.75 \\
\hline $\mathrm{T}_{5}$ & 842.0 & 66.7 & 91.3 & LS & 1.42 & 46.42 & 0.73 \\
\hline $\mathrm{T}_{6}$ & 834.7 & 73.3 & 92.0 & LS & 1.42 & 46.42 & 0.80 \\
\hline F-LSD $(p<0.05)$ & Ns & Ns & Ns & & 0.10 & 1.45 & Ns \\
\hline
\end{tabular}

$\mathrm{Ns}=$ not significant, $\mathrm{TC}=$ Textural Class, $\mathrm{BD}=$ Bulk density, $\mathrm{TP}=$ Total porosity, $\mathrm{SCR}=$ Silt-Clay ratio, $\mathrm{LS}=$ Loamy sand, $\mathrm{T} 1=\mathrm{Control}, \mathrm{T} 2=0$ ton ha ${ }^{1}+625 \mathrm{~kg} \mathrm{ha}^{-1} \mathrm{NPK}, \mathrm{T} 3=10 \mathrm{tha}^{-1} \mathrm{PWB}+625 \mathrm{~kg} \mathrm{ha}^{-1} \mathrm{NPK}, \mathrm{T} 4=10 \mathrm{tha}^{-1} \mathrm{PLB}+625 \mathrm{~kg} \mathrm{ha}^{-1} \mathrm{NPK}, \mathrm{T} 5=5 \mathrm{tha}^{-1} \mathrm{PWB}+5 \mathrm{tha}{ }^{-1}$ PLB $+625 \mathrm{~kg} \mathrm{ha}{ }^{-1} \mathrm{NPK}, \mathrm{T} 6=10$ $\mathrm{t} \mathrm{ha}^{-1} \mathrm{PWB}+10 \mathrm{t} \mathrm{ha}^{-1} \mathrm{PLB}+625 \mathrm{~kg} \mathrm{ha}^{-1} \mathrm{NPK}$; where: PWB = palm waste biochar, PLB = poultry litter biochar. LS = loamy sand.

Table 4: Effect of pyrolyzed agro-wastes on soil chemical properties

\begin{tabular}{|c|c|c|c|c|c|c|c|c|c|c|c|c|c|}
\hline Treatment & $\mathrm{pH}\left(\mathrm{H}_{2} \mathrm{O}\right)$ & $\mathrm{OC}$ & $\begin{array}{c}\text { OM } \\
\mathbf{g ~ k g}^{-1}\end{array}$ & TN & $\begin{array}{c}\text { AVP } \\
\mathrm{mg} \mathrm{kg}^{-1}\end{array}$ & $\mathrm{Ca}$ & Mg & $\begin{array}{c}\mathrm{Na} \\
\mathrm{cmol} \mathrm{kg}^{-1}\end{array}$ & $\mathbf{K}$ & TEA & TEB & ECEC & $\begin{array}{l}\text { BS } \\
\%\end{array}$ \\
\hline $\mathrm{T} 1$ & 5.25 & 7.20 & 12.41 & 0.62 & 5.30 & 1.33 & 0.87 & 0.07 & 0.17 & 1.07 & 2.44 & 3.51 & 69.52 \\
\hline $\mathrm{T} 2$ & 5.47 & 7.40 & 12.76 & 0.63 & 6.57 & 1.53 & 1.00 & 0.08 & 0.19 & 0.93 & 2.80 & 3.73 & 75.07 \\
\hline $\mathrm{T} 3$ & 6.07 & 9.00 & 15.52 & 0.70 & 6.58 & 1.80 & 1.13 & 0.11 & 0.21 & 0.77 & 3.25 & 4.02 & 80.85 \\
\hline $\mathrm{T} 4$ & 6.26 & 9.20 & 15.86 & 0.76 & 7.02 & 1.80 & 1.15 & 0.10 & 0.24 & 0.83 & 3.29 & 4.12 & 79.85 \\
\hline T5 & 6.10 & 8.10 & 13.96 & 0.80 & 6.59 & 1.68 & 1.10 & 0.10 & 0.19 & 0.77 & 3.07 & 3.84 & 79.95 \\
\hline T6 & 6.21 & 8.80 & 15.17 & 0.83 & 7.11 & 1.60 & 1.13 & 0.12 & 0.22 & 0.76 & 3.07 & 3.83 & 80.16 \\
\hline F-LSD) & 0.51 & 1.37 & 1.10 & 0.08 & 0.39 & 0.21 & 0.19 & 0.02 & 0.01 & 0.16 & 0.42 & 0.29 & 1.27 \\
\hline
\end{tabular}

$\mathrm{OC}=$ Organic carbon, $\mathrm{OM}=$ Organic matter, $\mathrm{TN}=$ Total nitrogen, $\mathrm{AVP}=$ Available phosphorus, TEA $=$ Total exchangeable acidity, $\mathrm{TEB}=\mathrm{Total}$ exchangeable bases, $\mathrm{ECEC}=$ Effective cation exchange capacity, $\mathrm{BS}=$ Base saturation. $\mathrm{T} 1=\mathrm{Control}, \mathrm{T} 2=0 \mathrm{t} \mathrm{ha}^{-1}+625 \mathrm{~kg} \mathrm{ha}^{-1} \mathrm{NPK}, \mathrm{T} 3=10 \mathrm{t} \mathrm{ha}^{-1} \mathrm{PWB}+625 \mathrm{~kg} \mathrm{ha}^{-1} \mathrm{NPK}$,

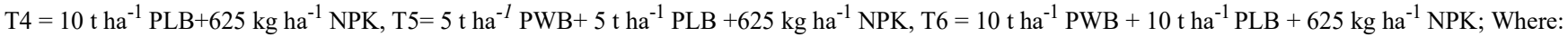
$\mathrm{PWB}=$ palm waste biochar, PLB = poultry litter biochar.

Comparing the pyrolyzed agro-wastes, the plots treated with $10 \mathrm{t} \mathrm{ha}^{-1} \mathrm{PWB}+625 \mathrm{~kg} \mathrm{ha}^{-1} \mathrm{NPK}$ had soil $\mathrm{pH}$ of 6.07 while plots treated with $10 \mathrm{t} \mathrm{ha}^{-1} \mathrm{PLB}+625 \mathrm{~kg} \mathrm{ha}^{-1} \mathrm{NPK}$ had a soil $\mathrm{pH}$ value of 6.26. The plots treated with $10 \mathrm{tha}^{-1} \mathrm{PWB}+10 \mathrm{t}$ $\mathrm{ha}^{-1}$ PLB $+625 \mathrm{~kg} \mathrm{ha}^{-1}$ NPK had a $\mathrm{pH}$ value of 6.21 while Control recorded the least soil $\mathrm{pH}$ of 5.25. The order of improvement was $\mathrm{T} 4>\mathrm{T} 6>\mathrm{T} 5>\mathrm{T} 3>\mathrm{T} 2>$ control. This was in line with the observations of Arocena and Opio (2003) and Khanna et al. (1994) who reported high soil $\mathrm{pH}$ when soils were treated with pyrolyzed organic materials. Ekebafe et al. (2013) reported that pyrolyzed agricultural products at $10 \mathrm{t}$ $\mathrm{ha}^{-1}$ made from palm fronts increased soil $\mathrm{pH}$ from 5.9 to 6.5 . Lehmann et al. (2002) attributed the increase in soil $\mathrm{pH}$ to ash accretion as ash residues are generally dominated by carbonates of alkali and alkaline earth metals, sesquioxides, phosphates and small amounts of organic and inorganic nitrogen. High $\mathrm{pH}$ on soils amended with pyrolyzed agrowastes could be traced to high $\mathrm{pH}$ of the palm waste and 
poultry litter biochar (Table 2). Soil carbon content was significantly $(p<0.05)$ increased by the application of biochar. Plots treated with $10 \mathrm{tha}^{-1} \mathrm{PWB}+$ NPK gave the highest organic carbon content. Plot without biochar recorded the lowest soil organic carbon of $7.20 \mathrm{~g} \mathrm{~kg}^{-1}$ while plots treated with $10 \mathrm{t} \mathrm{ha}^{-1} \mathrm{PLB}+625 \mathrm{~kg} \mathrm{ha}^{-1} \mathrm{NPK}$, (T4) recorded the highest value of $9.20 \mathrm{~g} \mathrm{~kg}^{-1}$. This was in line with the observations of Abebe et al. (2012), who reported a significant increase ( $>0.71$-unit increase compared to control) in soil organic carbon content when biochar from maize stalk was applied to soils. There was significant increase in the total nitrogen content of soil in the biocharamended plots (Table 4). Plots treated with $5 \mathrm{tha}^{-1} \mathrm{PWB}+5$ t ha ${ }^{-1}$ PLB $+625 \mathrm{~kg} \mathrm{ha}^{-1}$ NPK (T6) recorded nitrogen content of $0.83 \mathrm{~g} \mathrm{~kg}^{-1}$, followed by plots treated with $5 \mathrm{tha}^{-1} \mathrm{PWB}+5$ t ha-1 PLB $+625 \mathrm{~kg} \mathrm{ha}^{-1}$ NPK (T5) with $0.80 \mathrm{~g} \mathrm{~kg}^{-1}$ total N. The sequence of performance was $\mathrm{T} 6>\mathrm{T} 5>\mathrm{T} 4>\mathrm{T} 3>\mathrm{T} 2>$ control. Plots treated with $625 \mathrm{~kg} \mathrm{ha}^{-1} \mathrm{NPK}$ (T2) recorded available-P value of $6.57 \mathrm{mg} \mathrm{kg}^{-1}$ while plots treated with $5 \mathrm{t}$ $\mathrm{ha}^{-1}$ PWB $+5 \mathrm{t} \mathrm{ha}^{-1}$ PLB $+625 \mathrm{~kg} \mathrm{ha}^{-1}$ NPK (T5) recorded available $P$ of $6.59 \mathrm{mg} \mathrm{kg}^{-1}$. Control plots recorded the least available $P$ of $5.30 \mathrm{mg} \mathrm{g}^{-1}$ while plots treated with $10 \mathrm{t} \mathrm{ha}^{-1}$ PWB $+10 \mathrm{t} \mathrm{ha}^{-1}$ PLB $+625 \mathrm{~kg} \mathrm{ha}^{-1}$ NPK (T6) recorded the highest value of $7.11 \mathrm{mg} \mathrm{kg}^{-1}$ and plots treated with $10 \mathrm{t} \mathrm{ha}^{-1}$ PLB $+625 \mathrm{~kg} \mathrm{ha}^{-1}$ NPK (T4) recorded available P of $7.02 \mathrm{mg}$ $\mathrm{kg}^{-1}$. This was in concord with the findings of (Abebe et al. 2012 and Chan et al. 2008) who reported an increase in soil available-P after the application of biochar over time. The exchangeable calcium, magnesium, potassium and sodium of biochar-amended soils were higher when compared to the non-amended plots. Moreover, these values ranged from very low to moderate when compared to the standard critical values for exchangeable bases by Adaikwu and Ali (2013). Biochar application significantly $(p<0.05)$ increased the percentage base saturation relative to un-amended plots. This was in line with the observations of Chan et al. (2008), who reported increase in soil CEC and percentage base saturation after the application of biochars. Plots treated with $10 \mathrm{t} \mathrm{ha}^{-1}$ PWB $+625 \mathrm{~kg} \mathrm{ha}^{-1}$ NPK (T3) recorded the highest value of base saturation (80.85\%) while plots treated with $10 \mathrm{t} \mathrm{ha}^{-1}$ PLB+625 kg ha-1 NPK (T4) recorded base saturation of $79.85 \%$. Control plots recorded the least value of $69.52 \%$ followed by plots treated with sole mineral fertilizer (T2). An increase in percentage base saturation could be attributed to the high $\mathrm{pH}$ values of the biochar materials (Table 2). It has been observed by critical analysis that biochars possess high surface area and is highly porous, a variable charge organic material that has the potential to increase CEC, surface sorption capacity and percentage base saturation when added to the soil (Chan et al., 2008).

\section{Effect of pyrolyzed agro-wastes on the yield of maize}

Table 5 showed the results of pyrolyzed agro-wastes on the number of maize leaves. The treatments significantly $(p<0.05)$ influenced the number of maize leaves in relation to the control in the sixth and eighth weeks after planting. Plots treated with only inorganic fertilizer (T2) showed higher number of leaves at the early stage (4WAP). The rate of release of nutrients is much higher in the inorganic fertilizers since they provided major elements at the early stage of plant growth and development. Thus, plants exhibited accelerated growth rate than biochar-combined treated plots. At $6 \mathrm{WAP}$,

Table 5: Effect of palm waste biochar and poultry litter biochar on the number of maize leaves

\begin{tabular}{llll}
\hline Treatment & 4WAP & 6WAP & 8WAP \\
\hline T1 & 6.42 & 8.50 & 9.33 \\
T2 & 7.17 & 10.92 & 10.83 \\
T3 & 6.33 & 10.75 & 10.58 \\
T4 & 6.75 & 11.42 & 11.25 \\
T5 & 6.67 & 10.75 & 9.83 \\
T6 & 6.58 & 11.42 & 10.92 \\
F-LSD $(\boldsymbol{p}<\mathbf{0 . 0 5})$ & NS & $\mathbf{1 . 3 1}$ & $\mathbf{1 . 1 5}$
\end{tabular}

$\mathrm{WAP}=$ weeks after planting, $\mathrm{Ns}=$ not significant, $\mathrm{T} 1=$ Control, $\mathrm{T} 2=0$ $\mathrm{t} \mathrm{ha}^{-1}+625 \mathrm{~kg} \mathrm{ha}^{-1} \mathrm{NPK}, \mathrm{T} 3=10 \mathrm{t} \mathrm{ha}^{-1} \mathrm{PWB}+625 \mathrm{~kg} \mathrm{ha}^{-1} \mathrm{NPK}, \mathrm{T} 4=10$ $\mathrm{t} \mathrm{ha}^{-1} \mathrm{PLB}+625 \mathrm{~kg} \mathrm{ha}^{-1} \mathrm{NPK}, \mathrm{T} 5=5 \mathrm{tha}^{-1} \mathrm{PWB}+5 \mathrm{tha}^{-1}$ PLB +625 kg ha ${ }^{-1}$ NPK, T6=10 $\mathrm{t} \mathrm{ha}^{-1}$ PWB $+10 \mathrm{tha}^{-1}$ PLB $+625 \mathrm{~kg} \mathrm{ha}^{-1} \mathrm{NPK}$; Where: $\mathrm{PWB}=$ palm waste biochar, $\mathrm{PLB}=$ poultry litter biochar

Table 6: Effect of palm waste biochar and poultry litter biochar on the height of maize (cm)

\begin{tabular}{llll}
\hline Treatment & 4WAP & 6WAP & 8WAP \\
\hline T1 & 32.7 & 60.0 & 136.9 \\
T2 & 34.4 & 79.0 & 171.6 \\
T3 & 31.4 & 84.6 & 191.5 \\
T4 & 36.7 & 94.8 & 188.8 \\
T5 & 32.0 & 91.5 & 176.3 \\
T6 & 37.9 & 87.4 & 180.7 \\
F-LSD $(\boldsymbol{p}<\mathbf{0 . 0 5})$ & NS & $\mathbf{1 4 . 6 3}$ & $\mathbf{3 3 . 1 2}$ \\
\hline
\end{tabular}

$\mathrm{WAP}=$ weeks after planting, $\mathrm{Ns}=$ not significant, $\mathrm{T} 1=$ Control, $\mathrm{T} 2=$ $0 \mathrm{t} \mathrm{ha}^{-1}+625 \mathrm{~kg} \mathrm{ha}^{-1} \mathrm{NPK}, \mathrm{T} 3=10 \mathrm{tha}^{-1} \mathrm{PWB}+625 \mathrm{~kg} \mathrm{ha}^{-1} \mathrm{NPK}$, $\mathrm{T} 4=10 \mathrm{tha}^{-1} \mathrm{PLB}+625 \mathrm{~kg} \mathrm{ha}^{-1} \mathrm{NPK}, \mathrm{T} 5=5 \mathrm{tha}^{-1} \mathrm{PWB}+5 \mathrm{tha}^{-1}$ PLB $+625 \mathrm{~kg} \mathrm{ha}^{-1} \mathrm{NPK}, \mathrm{T} 6=10 \mathrm{tha}^{-1} \mathrm{PWB}+10 \mathrm{tha}^{-1} \mathrm{PLB}+625 \mathrm{~kg}$ $\mathrm{ha}^{-1} \mathrm{NPK}$. 
plots treated with $10 \mathrm{tha}^{-1}$ PLB $+625 \mathrm{~kg} \mathrm{ha}^{-1}$ NPK (T4) and $10 \mathrm{t} \mathrm{ha}^{-1}$ PWB $+10 \mathrm{t} \mathrm{ha}^{-1}$ PLB $+625 \mathrm{~kg} \mathrm{ha}^{-1}$ NPK (T6) gave the highest number of leaves. At $8 \mathrm{WAP}$, there was significant difference $(p<0.05)$ between the control and the amended plots. Plots amended with $10 \mathrm{t} \mathrm{ha}^{-1} \mathrm{PLB}+625 \mathrm{~kg} \mathrm{ha}^{-1} \mathrm{NPK}$ (T4) gave the highest number of maize leaves (11.25). Moreover, the high number of maize leaves were observed in plots treated with PLB $+625 \mathrm{~kg} \mathrm{ha}^{-1} \mathrm{NPK}$ (T4) due to the high levels of nitrogen and phosphorus in the poultry litter biochar (Table 2). Similar results were reported by Sarah et al. (2013) which showed that pyrolyzed agro-wastes have the capacity to increase the number of plant leaves by providing essential nutrients required.

The amendments increased the height of maize from 6 WAP as compared to control plots (Table 6). At 8 WAP, plots treated with $10 \mathrm{tha}^{-1} \mathrm{PWB}+625 \mathrm{~kg} \mathrm{ha}^{-1} \mathrm{NPK}$ (T3) recorded a higher plant height $(191.5 \mathrm{~cm})$. Plots treated with $10 \mathrm{t} \mathrm{ha}^{-1}$ PLB $+625 \mathrm{~kg} \mathrm{ha}^{-1}$ NPK (T4) recorded maize height of 188.75 $\mathrm{cm}$ while the lowest value was recorded from control soil $(136.92 \mathrm{~cm})$.

There was no significant difference in the maize leaf area at 4 WAP (Table 7). Higher value of leaf area was obtained in plots treated with $10 \mathrm{tha}^{-1}$ PLB $+625 \mathrm{~kg} \mathrm{ha}^{-1} \mathrm{NPK}$ (T4) relative to the control. Plots treated with $10 \mathrm{tha}^{-1} \mathrm{PWB}+625$ $\mathrm{kg} \mathrm{ha}^{-1}$ NPK (T3) gave the highest leaf area of $480.97 \mathrm{~cm}^{2}$ followed by plots treated with $10 \mathrm{tha}^{-1} \mathrm{PLB}+625 \mathrm{~kg} \mathrm{ha}^{-1} \mathrm{NPK}$ (T4) which recorded the value of $477.3 \mathrm{~cm}^{2}$. The sequence of performance was $\mathrm{T} 3>\mathrm{T} 4>\mathrm{T} 6>\mathrm{T} 2>\mathrm{T} 5>\mathrm{T} 1$. Thus, there was a positive impact of biochar on increasing maize leaf area when compared to T2 where only mineral fertilizer was applied. This is in accordance with the observations of Awodun et al. (2007) and Odeyemi et al. (2013) who reported a significant increase in the growth performance of crops when agro-waste was applied combined with NPK fertilizers. Thus, this was due to the high organic carbon contained in the pyrolyzed agro-wastes.

There significant $(p<0.05)$ increase in the straw dry matter yield and fresh cob yield while grain yield and harvest index showed no significant difference (Table 8). Plots amended with $10 \mathrm{t} \mathrm{ha}^{-1} \mathrm{PWB}+625 \mathrm{~kg} \mathrm{ha}^{-1} \mathrm{NPK}$ (T3) recorded higher dry matter yield of $10325 \mathrm{~kg} \mathrm{ha}^{-1}$. Plots treated with combinations of the pyrolyzed agro-wastes had less straw dry matter as against the plots amended with single pyrolyzed waste. The percentage increase in the straw dry matter yield on plots treated with biochars $(22.9 \%)$ over the plots treated with only mineral fertilizer (14.6\%) showed the positive impact of the pyrolyzed wastes in increasing the growth and

Table 7: Effect of palm waste biochar and poultry litter biochar on the leaf area of maize $\left(\mathrm{cm}^{2}\right)$

\begin{tabular}{|c|c|c|c|}
\hline Treatment & 4WAP & 6WAP & 8WAP \\
\hline $\mathrm{T} 1$ & 65.87 & 201.61 & 254.93 \\
\hline $\mathrm{T} 2$ & 100.43 & 260.73 & 458.79 \\
\hline T3 & 69.97 & 352.81 & 480.97 \\
\hline $\mathrm{T} 4$ & 95.53 & 365.3 & 477.25 \\
\hline T5 & 97.58 & 334.86 & 447.76 \\
\hline T6 & 97.44 & 343.74 & 464.72 \\
\hline F-LSD $(p<0.05)$ & Ns & 71.38 & 48.79 \\
\hline
\end{tabular}

Table 8: Effect of palm waste biochar and poultry litter biochar on the yield attributes of maize

\begin{tabular}{lcccc}
\hline Treatment & $\begin{array}{c}\text { Straw dry } \\
\text { matter yield } \\
\left(\mathbf{k g ~ h a}^{-1}\right)\end{array}$ & $\begin{array}{c}\text { Grain yield } \\
\left(\mathbf{t ~ h a}^{-1}\right)\end{array}$ & $\begin{array}{c}\text { \% Grain yield } \\
\text { increase over control }\end{array}$ & $\begin{array}{c}\text { Fresh cob } \\
\text { yield } \\
\left(\mathbf{t ~ h a} \mathbf{~}^{-1}\right)\end{array}$ \\
\hline T1 & 4725 & 2.18 & 0 & 4.03 \\
T2 & 8400 & 2.58 & 18.35 & 31.42 \\
T3 & 10325 & 2.65 & 21.56 & 23.60 \\
T4 & 9625 & 3.08 & 41.28 & 6.83 \\
T5 & 9100 & 2.46 & 12.84 & 7.53 \\
T6 & 8575 & 2.79 & 27.98 & 5.43 \\
F-LSD $(\boldsymbol{p}<\mathbf{0 . 0 5})$ & $\mathbf{2 9 3 9 . 4 2}$ & $\mathbf{N s}$ & - & 24.78 \\
\hline
\end{tabular}


yield of maize. This was in line with the observations of Major et al. (2010) who opined that biochar has the capacity to enhance maize development and growth.

Plots amended with $10 \mathrm{t} \mathrm{ha}^{-1}$ PLB+625 kg ha-1 NPK (T4) recorded the highest fresh cob weight of $7.53 \mathrm{t} \mathrm{ha}^{-1}$ followed by plots treated with $10 \mathrm{tha}^{-1} \mathrm{PWB}+625 \mathrm{~kg} \mathrm{ha}^{-1} \mathrm{NPK}$ (T3). The sequence of performance was $\mathrm{T} 4>\mathrm{T} 3>\mathrm{T} 6>\mathrm{T} 2>\mathrm{T} 5>$ control. The control plots gave the least grain yield $\left(2.18 \mathrm{t} \mathrm{ha}^{-1}\right)$ of maize. Also, plots treated with $10 \mathrm{t} \mathrm{ha}^{-1} \mathrm{PLB}+625 \mathrm{~kg} \mathrm{ha}^{-1} \mathrm{NPK}$ (T4) gave the highest percentage grain yield $(41.28 \%)$ over control. From these results, it can be deduced that higher grain yields were obtained from the plots treated with pyrolyzed photosynthesis, grain formation as well as fruit development. Result showed that biochar can be combined with mineral fertilizers to improve crop performance and subsequently enhance yield especially in acidic, low nutrient soils of the tropics. The highest percentage harvest index was recorded in the control (31.42\%), followed by plots treated with $10 \mathrm{tha}^{-1}$ PLB+625 kg ha ${ }^{-1}$ NPK (24.76\%). The lowest percentage harvest index was recorded in plots treated with $10 \mathrm{t} \mathrm{ha}^{-1}$ PWB $+625 \mathrm{~kg} \mathrm{ha}^{-1}$ NPK (20.48\%). The higher \% HI recorded in the control plots showed that the grain yield occupied a larger proportion of the plant total biomass, though with a lower yield when compared to plots treated with biochar.

Table 9: Effect of palm waste biochar and poultry litter biochar on nitrogen uptake and use efficiency of maize

\begin{tabular}{lllllllll}
\hline Treatment & $\begin{array}{l}\text { Amt. of N applied } \\
\left(\mathbf{k g ~ h a}^{-1}\right)\end{array}$ & $\begin{array}{l}\text { N-Straw } \\
(\mathbf{\%})\end{array}$ & $\begin{array}{l}\text { N-Grain } \\
(\mathbf{\%})\end{array}$ & $\begin{array}{l}\mathbf{N}-U p t a k e \\
\left(\mathbf{k g ~ h a}^{-1}\right)\end{array}$ & $\begin{array}{l}\mathbf{N}-N U E \\
(\mathbf{\%})\end{array}$ & $\begin{array}{l}\mathbf{A E} \\
\left(\mathbf{k g ~ k g}^{-1}\right)\end{array}$ & $\begin{array}{l}\mathbf{P F P} \\
\left(\mathbf{k g ~ k g}^{-1}\right)\end{array}$ & $\begin{array}{l}\mathbf{P E} \\
\left.\mathbf{( k g ~ k g}^{-1}\right)\end{array}$ \\
\hline T1 & 0 & 1.56 & 1.9 & 41.42 & - & - & - & - \\
$\mathrm{T} 2$ & 93.75 & 1.9 & 2.4 & 61.92 & 21.87 & 4.27 & 27.52 & 19.51 \\
T3 & 93.75 & 1.84 & 2.45 & 64.93 & 25.08 & 5.01 & 28.27 & 20 \\
$\mathrm{~T} 4$ & 93.75 & 2.1 & 2.3 & 70.84 & 31.38 & 9.60 & 32.85 & 30.6 \\
T5 & 93.75 & 1.91 & 2.5 & 61.5 & 21.42 & 2.99 & 26.24 & 13.94 \\
T6 & 93.75 & 2.31 & 2.65 & 73.94 & 34.69 & 6.51 & 29.76 & 18.76 \\
\%CV & & $\mathbf{1 3 . 0 5}$ & $\mathbf{1 0 . 8 3}$ & $\mathbf{1 8 . 2 9}$ & $\mathbf{5 4 . 3 6}$ & $\mathbf{6 8 . 5 6}$ & $\mathbf{4 9 . 8 8}$ & $\mathbf{5 8 . 4 5}$ \\
\hline
\end{tabular}

$\mathrm{NNUE}=$ nitrogen use efficiency, $\mathrm{AE}=$ agronomic efficiency, $\mathrm{PFP}=$ partial factor productivity, $\mathrm{PE}=$ physiological efficiency. $\mathrm{CV}=0-15 \%$, Low variability; $\mathrm{CV}=15-35 \%$, Medium variability; $\mathrm{CV}=>35 \%$, High variability. $\mathrm{T} 1=$ Control, $\mathrm{T} 2=0 \mathrm{tha}^{-1}+625 \mathrm{~kg} \mathrm{ha}^{-1} \mathrm{NPK}, \mathrm{T} 3=10 \mathrm{tha}{ }^{-1} \mathrm{PWB}+625 \mathrm{~kg}$ ha ${ }^{-1} \mathrm{NPK}, \mathrm{T} 4=$ $10 \mathrm{tha}^{-1} \mathrm{PLB}+625 \mathrm{~kg} \mathrm{ha}^{-1} \mathrm{NPK}, \quad \mathrm{T} 5=5 \mathrm{tha}^{-1} \mathrm{PWB}+5 \mathrm{tha}^{-1} \mathrm{PLB}+625 \mathrm{~kg} \mathrm{ha}^{-1} \mathrm{NPK}, \mathrm{T} 6=10 \mathrm{tha}^{-1} \mathrm{PWB}+10 \mathrm{tha}^{-1} \mathrm{PLB}+625 \mathrm{~kg}$ ha ${ }^{-1} \mathrm{NPK} ; \mathrm{PWB}=\mathrm{palm}^{-1}$ waste biochar, PLB = poultry litter biochar.

Table 10: Effect of palm waste biochar and poultry litter biochar on phosphorus uptake and use efficiency of maize

\begin{tabular}{lllllllll}
\hline Treatment & $\begin{array}{l}\text { Amt. of N applied } \\
\left(\mathbf{k g ~ h a}^{-1}\right)\end{array}$ & $\begin{array}{l}\text { P-Straw } \\
(\mathbf{\%})\end{array}$ & $\begin{array}{l}\text { P-Grain } \\
\mathbf{( \% )}\end{array}$ & $\begin{array}{l}\text { P-Uptake } \\
(\mathbf{k g ~ h a}\end{array}$ & $\begin{array}{l}\text { P-NUE } \\
(\mathbf{\%})\end{array}$ & $\begin{array}{l}\text { AE } \\
\left(\mathbf{k g ~ k g}^{-1}\right)\end{array}$ & $\begin{array}{l}\text { PFP } \\
\left(\mathbf{k g ~ k g}^{-1}\right)\end{array}$ & $\begin{array}{l}\text { PE } \\
\left.\mathbf{( k g ~ k g ~}^{-1}\right)\end{array}$ \\
\hline T1 & 0 & 0.82 & 2.1 & 45.78 & - & - & - & - \\
T2 & 40.88 & 1.75 & 2.2 & 56.76 & 26.86 & 9.78 & 63.11 & 36.43 \\
T3 & 40.88 & 1.8 & 2.2 & 58.3 & 30.63 & 11.5 & 64.82 & 37.54 \\
T4 & 40.88 & 1.92 & 2.55 & 78.54 & 80.14 & 22.02 & 75.34 & 27.47 \\
T5 & 40.88 & 2.0 & 2.4 & 59.04 & 32.44 & 6.85 & 60.18 & 21.12 \\
T6 & 40.88 & 2.15 & 2.7 & 75.33 & 72.28 & 14.92 & 68.25 & 20.64 \\
\%CV & & $\mathbf{2 7 . 1 8}$ & $\mathbf{9 . 8 9}$ & $\mathbf{1 9 . 8 4}$ & $\mathbf{7 4 . 8 5}$ & $\mathbf{6 8 . 5 9}$ & $\mathbf{4 9 . 8 9}$ & $\mathbf{5 7 . 6 1}$ \\
\hline
\end{tabular}

$\mathrm{P}-\mathrm{NUE}=$ phosphorus use efficiency, $\mathrm{AE}=$ agronomic efficiency, $\mathrm{PFP}=$ partial factor productivity, $\mathrm{PE}=$ physiological efficiency. $\mathrm{CV}=0-15 \%$, Low; $\mathrm{CV}=15$ $35 \%$, Medium; $\mathrm{CV}=>35 \%$, High. T1 $=$ Control, T2 $=0 \mathrm{t} \mathrm{ha}^{-1}+625 \mathrm{~kg} \mathrm{ha}^{-1} \mathrm{NPK}, \mathrm{T} 3=10 \mathrm{tha}^{-1} \mathrm{PWB}+625 \mathrm{~kg} \mathrm{ha}^{-1} \mathrm{NPK}, \mathrm{T} 4=10 \mathrm{tha}{ }^{-1} \mathrm{PLB}+625 \mathrm{~kg}$ ha ${ }^{-1} \mathrm{NPK}$, $\mathrm{T} 5=5 \mathrm{t} \mathrm{ha}^{-1} \mathrm{PWB}+5 \mathrm{t} \mathrm{ha}^{-1} \mathrm{PLB}+625 \mathrm{~kg} \mathrm{ha}^{-1} \mathrm{NPK}, \mathrm{T} 6=10 \mathrm{tha}^{-1} \mathrm{PWB}+10 \mathrm{tha}^{-1} \mathrm{PLB}+625 \mathrm{~kg} \mathrm{ha}^{-1} \mathrm{NPK}$; PWB = palm waste biochar, PLB $=$ poultry litter biochar.

agro-wastes (biochars). The order of increase in grain yield was $\mathrm{T} 4>\mathrm{T} 6>\mathrm{T} 3>\mathrm{T} 2>\mathrm{T} 5>$ control. Therefore, the application of pyrolyzed ago-wastes had a positive effect on the yield of maize. The higher yield in plots treated with $10 \mathrm{t} \mathrm{ha}^{-1} \mathrm{PLB}+625$ $\mathrm{kg} \mathrm{ha}^{-1}$ NPK (T4) could be attributed to nutrient contained in PLB especially $\mathrm{N}, \mathrm{P}$ and $\mathrm{K}$ which are important in

\section{Effect of pyrolyzed agro-wastes on phosphorus and nitrogen use efficiency}

Effects of biochars on $\mathrm{N}$ and $\mathrm{P}$ use efficiency are presented in Tables 9 and 10, respectively. Plots treated with $10 \mathrm{t} \mathrm{ha}^{-1} \mathrm{PWB}+10 \mathrm{tha}^{-1} \mathrm{PLB}+625 \mathrm{~kg} \mathrm{ha}^{-1} \mathrm{NPK}$ recorded the highest value of N-uptake $\left(73.94 \mathrm{~kg} \mathrm{ha}^{-1}\right)$ and this was 
followed by plots treated with $10 \mathrm{t} / \mathrm{ha}$ PLB $+625 \mathrm{~kg} \mathrm{ha}^{-1} \mathrm{NPK}$ $\left(70.84 \mathrm{~kg} \mathrm{ha}^{-1}\right)$. According to Pietikainen et al. (2000), biochar inhabits soil microorganisms that play an important role in $\mathrm{N}, \mathrm{P}$ or $\mathrm{S}$ dynamics. Plots treated with $10 \mathrm{t} \mathrm{ha}^{-1}$ PLB $+625 \mathrm{~kg} \mathrm{ha}^{-1} \mathrm{NPK}$ recorded the highest P-uptake of 78.54 $\mathrm{kg} \mathrm{ha}^{-1}$ followed by plots treated with $10 \mathrm{tha}^{-1} \mathrm{PWB}+10 \mathrm{tha}$ ${ }^{1}$ PLB $+625 \mathrm{~kg} \mathrm{ha}^{-1}$ NPK (75.33 kg ha-1). Control plots showed lowest P-uptake ( $\left.45.78 \mathrm{~kg} \mathrm{ha}^{-1}\right)$ followed by the plots treated with mineral fertilizer $\left(56.76 \mathrm{~kg} \mathrm{ha}^{-1}\right)$. Plots treated with $10 \mathrm{t} \mathrm{ha}^{-1}$ PWB $+10 \mathrm{t} \mathrm{ha}^{-1}$ PLB $+625 \mathrm{~kg} \mathrm{ha}^{-1}$ NPK recorded the highest N-NUE of $34.69 \%$ followed by the plots treated with $10 \mathrm{t} \mathrm{ha}^{-1}$ PLB+625 $\mathrm{kg} \mathrm{ha}^{-1}$ NPK (31.38\%).

Like N-NUE, phosphorus use efficiency (P-NUE) showed high variability between the treatment means $(74.85 \%)$. Plots treated with $10 \mathrm{t} \mathrm{ha}^{-1} \mathrm{PLB}+625 \mathrm{~kg} \mathrm{ha}^{-1}$ NPK (T4) recorded the highest P-NUE of $80.14 \%$ followed by plots treated with $10 \mathrm{tha}$ ${ }^{1} \mathrm{PWB}+10 \mathrm{t} \mathrm{ha}^{-1} \mathrm{PLB}+625 \mathrm{~kg} \mathrm{ha}^{-1} \mathrm{NPK}$ (T6) (72.28\%). Plots treated with NPK fertilizers recorded least P-NUE (26.86\%). This was in concord with the observations of Abebe et al. (2012), who reported similar effects of biochar on N-uptake and P-uptake in lettuce. The observed increase in N-uptake, Puptake, N-NUE and P-NUE with biochar applications indicated the potential of biochar in improving nutrient use efficiencies especially in soils of the tropics where fertility depends highly on N, P and $\mathrm{K}$ availability.

Results of nitrogen Agronomic Efficiency (AE), Partial Factor Productivity (PFP) and Physiological Efficiency (PE) are presented in Table 9. Plots amended with $10 \mathrm{tha}^{-1} \mathrm{PLB}+625 \mathrm{~kg}$ $\mathrm{ha}^{-1} \mathrm{NPK}$ (T4) recorded the highest N AE, PFP and PE of $9.6 \mathrm{~kg}$ $\mathrm{ha}^{-1}, 32.85 \mathrm{~kg} \mathrm{ha}^{-1}$ and $30.6 \mathrm{~kg} \mathrm{ha}^{-1}$, respectively. The lowest values of $\mathrm{N} A \mathrm{AE}, \mathrm{PFP}$ and PE were recorded on plots treated with $5 \mathrm{t} \mathrm{ha}^{-1}$ PWB $+5 \mathrm{t} \mathrm{ha}^{-1}$ PLB $+625 \mathrm{~kg} \mathrm{ha}^{-1}$ NPK. Results on phosphorus PE, AE and PFP are presented in Table 10. Plots amended with $10 \mathrm{tha}^{-1} \mathrm{PLB}+625 \mathrm{~kg} \mathrm{ha}^{-1} \mathrm{NPK}$ (T4) recorded the highest P AE and PFP of 22.02 and $75.34 \mathrm{~kg} \mathrm{ha}^{-1}$, respectively, while plots treated with $10 \mathrm{tha}^{-1} \mathrm{PWB}+625 \mathrm{~kg} \mathrm{ha}^{-1}$ NPK (T3) recorded the highest PE of $37.54 \mathrm{~kg} \mathrm{ha}^{-1}$. According to Baligar et al. (2001), Partial Factor Productivity (PFP), Physiological Efficiency (PE) and Agronomic Efficiency (AE), are the main indicators of crop response to amendment practice. St. Kalinova and Hristoskov (2014) have reported values for N-PFP to be 37$53 \mathrm{~kg} \mathrm{ha}^{-1}$ and N-AE to be $2-10 \mathrm{~kg} \mathrm{ha}^{-1}$ on soils treated with mineral fertilizers in maize fields.

\section{Conclusions}

The wok has shown that pyrolyzed agro-wastes have proved effective in the improvement of soil properties, growth and yield of maize. There was significant effect on fresh cob yield, $\mathrm{N}$ and $\mathrm{P}$ uptakes as well as nutrient use efficiency with the application of pyrolyzed palm waste biochar and poultry litter biochar. Plots amended with $10 \mathrm{tha}$ ${ }^{1} \mathrm{PLB}+625 \mathrm{~kg} \mathrm{ha}^{-1}$ NPK gave the highest maize grain and maize fresh cob yield when compared to other treatments. The highest values of $\mathrm{N}$ uptake, $\mathrm{P}$ uptake and $\mathrm{N}$ and $\mathrm{P}$ nutrient use efficiency were obtained with application of $10 \mathrm{tha}^{-1}$ PLB $+625 \mathrm{~kg} \mathrm{ha}^{-1} \mathrm{NPK}$ fertilizer. The application of biochar increased the $\mathrm{pH}$ of acid soil and therefore should be adopted as liming material. Among the treatments evaluated, $10 \mathrm{tha}^{-1}$ PLB $+625 \mathrm{~kg} \mathrm{ha}^{-1}$ NPK fertilizer increased the yield of maize more than other treatments. This rate is recommended for optimum maize yield. Since N and P are major nutrients that are always deficient in acidic soils, application of $10 \mathrm{tha}^{-1}$ PLB $+625 \mathrm{~kg} \mathrm{ha}^{-1}$ NPK fertilizer may be adopted for effective nutrient management of these nutrients.

\section{Acknowledgement}

The assistance of Mr. Anyanwu, D. C of Imo State Agricultural Development Programme (ADP) during the pyrolysis process at Ohaji Egbema, Imo State and $\mathrm{Mr}$. Udensi, of the Federal College of Land Resources Technology Owerri (FECOLART) who helped during soil sampling and analyses is highly appreciated.

\section{References}

Abebe, N, K. Endalkache, M. Mastawesha and A. Gebermedihin. 2012. Effect of biochar application on soil properties and nutrient uptake of lettuces (Lactuca sativa) grown in chromium polluted soils. American-Eurasian Journal of Agriculture. and Environmenal Sciences 12(3): 369-376.

Adaikwu, A.O. and A. Ali. 2013. Assessment of some quality indicators in Benue State. Nigerian Journal of Soil Science 23(2): 66-75.

Agnieszka, W., G.G. Andrzej, B. Jan and K. Marcin. 2013.Visualizing harvest index in crops. Communications in Biometry and Crop Science 8(2): 48-59.

Aisha, A.H., F.A. Rizk, A.M, Shaheen and M.M. AbdelMouty. 2007. Onion plant growth, bulbs yield and its physical and chemical properties as affected by organic and natural fertilization. Research Journal of Agriculture and Biological. Sciences 3(5):380-388.

Amanullah, I., M.K. Khair, K. Azam, K. Imran, S. Zahir and H. Zahid. 2014. Growth and yield response of maize (Zea mays L.) to foliar NPK-fertilizers under moisture stress condition. Soil and Environment 33(2): 116-123.

Arocena, J.M. and C. Opio. 2003. Prescribed fire-induced changes in properties of Sub-Boreal forest soils. Geoderma 113:1-6. 
Awodun, M.A., L.I. Omonijo and S.O. Ojeniyi. 2007. Effect of goat dung and NPK fertilizer on soil and leaf nutrient content, growth and yield of pepper. International Journal of Soil Science 2(2): 142-147.

Baligar, V.C., N.K. Fageria and Z.I. He. 2001. Nutrient use efficiency in plants. Communication Soil Science Plant Analysis 32(7, 8): 921-950.

Brady, N.C. and R.R. Weil. 1999. The Nature and Properties of Soils. $12^{\text {th }}$ Ed., Printice- Hall Inc., New Jersey, USA. Pp. 785.

Bremner, J.M. and C.S. Mulvaney. 1982. Total nitrogen. p. 595-624. In: Methods of Sol Analysis, part 2. A.L. Page, R.H. Mille and D.R. Keeney (Eds.). American Society of Agronomy, Maidison, W.I.

Chan, K.Y., L. Van Zwieten, I. Meszaros, A. Downie and S. Joseph. 2008. Using poultry litter biochars as soil amendments. Australian Journal Soil Research 46: 437444.

Ekebafe, M.O., P. Oviasogie and N.O. Asueni. 2015. Laboratory incubation studies of biochar amendment on non- $\mathrm{Co}_{2}$ greenhouse gas emissions from soil cultivated to coconut seedlings. Nigerian Journal of Soil Science 23(2): 1- 27

Enwezor, W.O, E.J. Udo, N.J. Usoroh, K.A. Ayotade, J.A. Adepetu, V.O. Chude and C.I. Udegbe. 1989. Fertilizer Use and Management Practices for Crops in Nigeria. Series No 2. Bobma Publishers Ibadan, Nigeria.

Food and Agricultural Organization. 2006. Guidelines for Soil Description. 4th Ed. Food and Agriculture Organization of the United Nations (FAO), Rome, Italy.

Federal Directorate of Agriculture and Land Resources. 1985. Reconnaissance Soil Survey of Anambra State of Nigeria, Soil Reports 1985, Federal Department of Agriculture and Land Resources, Lagos, Nigeria.

Fitzpatrick, F. A. 1986. An Introduction to Soil Science. 2nd Ed., Longman Scientific and Technical, New York, USA.

Gee, G.W. and D. Or. 2002. Particle size analysis. p. 225-293. In: Methods of Soil Analysis. Physical Methods. D.J. Dan and G.C. Topps (ed.). Soil Science Society of America Book Series.No.5, ASA and SSSA Madison, WI.

Hendershot, W.H, H. Lalande and M. Dequette. 1993. Soil reaction and exchangeable acidity. p. 141-145. In: Soil Sampling and Methods of Soil Analysis. M.R. Carter (ed.). Canadian Society of Soil Science, Lewis Publishers, London.

Khanna, P.K, R. J. Raison and R. A. Falkiner. 1994. Chemical properties of ash derived from Eucalyptus litter and its effects on forest soils. Forest Ecology Management. 66:107-125.
Lehmann, J., J.P. Silva, M. Rondon, M.S. Cravo, J. Greenwood, T. Nehls, C. Steiner and B. Glaser. 2002. Slash-and-char-a feasible alternative for soil fertility management in the central Amazon. $17^{\text {th }}$ World Congress of Soil Science, Bangkok, paper No. 449.

Lehmann, J., C. R. Matthias, T. Janice, A.M. Caroline, C.H. William and C. David. 2011. Biochar effects on soil biotaA review 43: 1812-1836.

Major, J., M. Rondon, D. Molina, J. Rihan-Susan and J. Lehmann. 2010. Maize yield and nutrition during 4 year after biochar application to a Colombian savannah oxisol. Plant and Soil 333:117-128.

Malcom, J.H. 2012. Improving nutrient use efficiency in crops. Roth Amsted Research Harpenden, Hertfordshire, UK.

McLean, E.D. 1982. Soil pH and lime requirements. p. 199234. In: Methods of Soil Analysis part 2. Chemical and Microbial Properties ( $2^{\text {nd }}$ Ed.). A.L. Page (ed.). Agronomy Series. SSSA, Madison, USA.

Muhammad, M.B., A. Wiqar, A. Murad and K. Farmanullah. 2018. Effect of biochar particle size and biofertilizers on lentil (Lense culinarous M.) yield and available fractions of soil nutrients. Soil and Environment 37(2): 143-15.

Nelson, D.W. and L.E. Sommers. 1982. Total organic carbon and matter. p. 570. In: Methods of soil analysis. Part 2 Chemical and Microbiological Properties ( $\left.2^{\text {nd }} E d.\right)$. A.L. Page (ed.). Agronomy Series No.9, ASA, SSSA, Maidison Wis. USA.

Nwafor, O.E., S.O. Adepoju, A.A. Mba, M.C. Okonkwo, M. Emefiene and K. Aminu. 2010. The effect of manual weeding intervals on the yield of watermelon (Citrulus lanatus) in Jos metropolis, Nigeria. Proceedings of the $24^{\text {th }}$ Annual Conference of Farm Management Association of Nigeria. September 6-9, 2010. Adamawa State University, Mubi, Nigeria.

Nwonuala, A.I., S.U. Onwudike and E.U. Onweremadu. 2013. Agronomic performance of okra (Abelmoschus esculentus L.) as influenced by cattle manure and tillage practices in southeastern Nigeria. Acta Agronomica Nigeriana 13(1, 2): 64-70.

Odeyemi, R.T., M.A. Awodun and S.O. Ojeniyi. 2013. Combine effect of poultry manure and NPK fertilizer on soil plant nutrient composition and growth of rubber. Nigerian Journal of Soil Science 23(2): 136-141.

Olsen, S.R. and I.E. Sommers. 1982. Soil available phosphorus. p.403-430. In: Methods of Soil Analysis, part 2. D.L. Sparks, A.L. Page, P.A. Hennke, K.H. Loppez, E.N. Solanpour and M.E (eds.). Summers. American Society of Agronomy and Soil Science Society of America, Maidison, USA. 
Onwudike, S.U., D.O. Asawalam and A.O. Ano. 2015. Comparative evaluation of burnt and unburnt agro-wastes on soil properties and growth performance of Cocoyam in a humid environment. Asian Journal of Agricultural Research 9(6): 276-295.

Paul, F., F. Brentrup, T. Brulsema, F. Garcia, R. Norton and S. Zingore. 2014. Fertilizer use efficiency: Measurement, current situation and trends. International Fertilizer Industry Association, Paris, France.

Pietikainen, J., A. Kikkila and H. Fritze. 2000. Charcoal as a habitat of microbes and its effect on the microbial community of the underlying humus. Oikos 89:231-242.

Post, W.M and K.C. Kwon. 2000. Soil carbon sequestration and land-use change: Processes and potential. Global Change Biology 6(3): 317-328.

DOI: $10.1046 /$ j.1365-2486.2000. 00308.x

Sarah, C., S. Simon, S. Saran, S. Tan Boun and H. Stephan. 2013. The impact of biochar application on soil properties and plant growth of pot grown Lettuce (Lactuc sativa) and Cabbage (Brassica chinensis). Agronomy 3: 404-418.

Seran, T.H., S. Srikrishnah and M.M. Ahamed. 2010. Effect of different levels of inoraganic fertilizers and compost as basal application on the growth and yield of onion (Allium cepa L.). Sri Lanka, University Press.
Sharma, N.K., J.S. Raman and K. Kuldeep. 2012. Dry matter accumulation and nutrient uptake by wheat (Triticumaestivum 1.) under poplar (Populus deltoids) based agroforestry system. ISRN Agronomy. pp 1-7.

Soil Survey Staff. 2003. Keys to Soil Taxonomy. $9^{\text {th }}$ Ed. United States Department of Agriculture. Washington DC.

Stewart, M.W., W.D. Dibb, E.A. Johnston and J.T. Smyth. 2005. The contribution of commercial fertilizer nutrients to food production. Agronomy Journal 97:1-6.

St. Kalinova, K.D and S. Hristoskov. 2014. Nitrogen use efficiency and maize yield response to nitrogen rate and foliar fertilizing. Bulgarian Journal of Agricultural Science 20(1): 178-181.

Thomas, G.W. 1982. Exchangeable cations. p. 159-165. In: Methods of Soil Analysis part 2. A.L. Page, R.H. Miller and D.R. Keeney (eds.). Agron. Monogr. 9, American Society Agronomy and Soil Science Society America Madison. WI. 